\title{
Beleza pura. A estetização da vida cotidiana como estratégia de resistência para o homossexual masculino*
}

\section{RESUMO}

Este artigo pretende debater como a estetização da vida cotidiana serviu às estratégias de resistência dos homossexuais masculinos frente às práticas reguladoras do poder sobre seus corpos e sua imagem. Tomamos por princípio que estes sujeitos criaram produtos imagéticos com o objetivo de delinear um estilo de vida baseado no prazer estético. Nossa operação analítica concentra-se em alguns materiais expressivos que serviram à divulgação de sua linguagem. Acreditamos que esta linguagem foi fortalecida pelo uso do corpo e seus gestos, na comunicação efetuada pela roupa e na circulação de palavras e imagens, próprias às artes e a literatura. Reivindicamos uma dimensão sensível do processo comunicacional para descrever os modos de interação entre estes sujeitos.

\section{PALAVRAS-ChAVE \\ Corpo \\ Homossexualidade \\ Imagem}

Pure beauty. The aesthetics of everyday life as a strategy of resistance to the male homosexual

\section{ABSTRACT}

This article aims to explore how the aesthetics of everyday life served to the resistance strategies of gay men facing the regulatory practices of power over their bodies and their image. We take the principle that these subjects have created products imagistic in order to design a lifestyle based on aesthetic pleasure. Our analytical operation focuses on some expressive materials that served as the disclosure of their language. We believe that this language was strengthened by the use of the body and gestures, the communication made by machine and the movement of words and images, suitable to the arts and literature. We demand a significant dimension of the communication process to describe the modes of interaction between these subjects.

\section{KEYWORDS}

\author{
Body \\ Homosexuality \\ Image
}

\section{Carlos Magno Camargos Mendonça Professor do Programa de Pós-Graduacão em Comunicacãão Social da UFMG/MG/BR macomendonca@gmail.com}

Ao longo da história humana a representação do corpo homossexual oscilou entre o retrato do corpo abjeto ou a personificação da ilegalidade. Em diferentes condições espaço-temporais, o discurso que nomina este corpo foi e é forjado a partir de uma matéria-prima coletada na cultura heterossexual dominante. Corpos e signos eram amalgamados com o objetivo de caracterizar um modo de vida a ser evitado. Como estratégia de dominação, a imposição de um sentido sobre o corpo pelos discursos religiosos, jurídicos ou médicos representou a tentativa de unificar as interpretações das práticas homossexuais. O controle do enunciado sobre os corpos é o controle de seus desejos e de suas performances gestuais, culturais e sociais.

Nominar a experiência dos corpos, regular o dizer sobre ela, é um importante instrumento utilizado nas estratégias de controle. Dentro dos limites da linguagem, as táticas de regulação querem apanhar o corpo e seus desejos. Entretanto, é também dentro destes limites que o corpo luta por liberdade. Dominante e dominado, sem alcançarem a totalidade do dizível, combatem pela propriedade do significado. Nesta batalha, os dominados lutam contra a imposição de um significante sobre seus corpos e ações pelo dominador. Esta imposição tem o objetivo de criar um corpo simbólico único, regulado, sem marcas ou diferenças.

Fortalecer a diferença através do uso de imagens e palavras configura-se como uma estratégia de resistência frente ao condicionamento simbólico dos corpos. As 
imagens possuem um papel fundamental na encenação social, pois elas tanto condicionam quanto oferecem linhas de fugas à subjetividade. Cabe àquele que resiste a criação de outro mundo imaginal, onde a pregnância das imagens ofereça a renovação do sentido e descortine a erótica aglutinadora de seus corpos.

\section{Para uma nova inscrição nos campos da culfura e para a autodeferminação de sua imagem, os homossexuais criaram formas de comunicação capazes de ampliar sua voz.}

$\mathrm{Na}$ desigual disputa discursiva dentro da arena pública, eles encontraram nas imagens uma oportunidade para enunciar ao outro sua forma de estar no mundo. Alicerçados na estetização promovida pelos materiais expressivos da arte e da literatura, os homossexuais investiram em uma poética da vida ordinária que conjugasse as potências advindas das imagens e dos meios primários de comunicação. Para Harry Pross (Beth; Pross, 1990), os meios primários de comunicação são os meios elementares do contato humano, uma comunicação que prioriza os cinco sentidos do corpo. Pross considera que é neste tipo de comunicação que trocamos impressões com o outro. Segundo ele, é na troca direta de impressões com o outro que podemos descobrir o que temos em comum. O sentimento comum favorece o nascimento da solidariedade. A dimensão estética dos fenômenos cotidianos do mundo homossexual, quando foi colocada em circulação, favoreceu o fortalecimento da subjetividade daqueles indivíduos a partir de uma mudança de rumo na descrição de seus territórios existenciais.

Ao invocar uma estética da comunicação para observar os modos de interação entre os sujeitos admitimos que subsiste uma dimensão sensível no processo comunicacional. Tal dimensão nós afasta de uma compreensão da comunicação como sistema de transmissão de informações e nos conduz ao entendimento desta como algo dinâmico, plural e em permanente transformação. Nos estudos da comunicação, o reconhecimento da existência de uma comunicabilidade estética nos impõe a observação da matriz cultural própria às interações humanas. Nesta matriz, os indivíduos não estariam sujeitados apenas aos padrões transmissivos e reguladores dos sistemas informacionais. Eles lançam mão de seus gostos e prazeres como mecanismos para ampliar sua presença no mundo. Estes gostos e prazeres não espelham ações individualizadas, mas emoções partilhadas e hábitos familiares entre o sujeito e seu grupo.

\section{O valor da experiência}

No século XIX, a consolidação de um universo de referência estético ainda não era capaz de retirar a experiência homossexual da clandestinidade. À medida que avançavam no domínio de sua imagem, os homossexuais sofriam as consequências do aumento na radicalização política, social e cultural que tentava conter suas experiências. A maquinaria do poder produziu enunciados para demonstrar como a experiência homossexual feria as experiências primárias. Nas estratégias do poder, as experiências primárias possuíam um caráter de fatos da natureza e desligadas da condição de acontecimentos sociais. Desse modo, os costumes, os valores morais e religiosos apontavam a experiência homossexual como antinatural, como um risco à familia e como uma ameaça à sociedade. Para John Dewey, as experiências primárias são reguladas pelos valores morais e legais de uma determinada sociedade. Como são tipos de experiências anteriores ao ingresso do sujeito na vida social, as experiências primárias parecem imutáveis e possuidoras de uma verdade inabalável.

Quando investigamos os registros, especialmente da segunda metade do século XIX em diante, que revelam o modo pelo qual os homossexuais se organizaram socialmente para defender seus direitos, reconhecemos um esforço do coletivo para demonstrar que o sujeito era o centro da experiência. Assim sendo, os acontecimentos éticos e estéticos que os envolviam e os saberes decorrentes dessas experiências poderiam ser agentes transformadores das experiências primárias. Como prática de resistência, os homossexuais socializaram suas experiências homoafetivas. O processo de socialização ocorreu no registro e na circulação de palavras, gestos e imagens que valorizavam as formas possíveis de estar junto, de se ligar ao outro, de manifestar o desejo e nas maneiras de se mostrar ao mundo. Esse processo teve a intenção de dar a vida um gozo estético, aberta a novas sensações e prazeres. Neste sentido, a estetização dos comportamentos foi um ato político. 
É possível pensar a criação de um mundo estetizado pelos homossexuais como estratégias de resistência quando convocamos para o raciocínio uma dimensão pragmatista da experiência. Para sermos mais específicos, um pragmatismo aos modos de Dewey, colorido com tons humanistas, que observou a experiência como uma conjunção do cognitivo com os princípios éticos e sociais. Nesta dimensão, a experiência é uma interação entre o organismo e o ambiente. O organismo é um agente de mudança que na experiência encontra o sofrer e o agir. Para John Dewey, a experiência é um processo impessoal de onde emerge o sujeito, ela conecta sujeito e objeto, coisa e pensamento. De acordo com o filósofo, em uma perspectiva objetiva, a história será sempre composta por rios, planícies e florestas, bem como pelas instituições e suas legislações; em uma perspectiva subjetiva, a historia incluirá propósitos e planos, os desejos e as emoções, através dos quais aquelas coisas próprias à perspectiva objetiva são administradas e transformadas2.

O valor da experiência está no fato dela guardar em si a vida dos sujeitos. É a partir do experienciado que os prazeres, os sabores, os saberes ganham ou perdem importância. Viver é compreender e sentir, portanto controlar a experiência é regular as crenças e os desejos.

\section{Frente ao silêncio das palavras, a comunicabilidade das imagens}

\section{Nos momentos em que o dizer da experiência homossexual foi silenciado, as imagens fornaram-se narradoras fundamentais dessa experiência e mefaforizaram o desejo proibido no centro mesmo das instifuições reguladoras, como foi o caso das imagens religiosas.}

As pinturas que retratavam os santos eram, muitas das vezes, carregadas de um sentido erótico. Nos quadros de
Caravaggio, São Francisco em êxtase (1559), O sacrificio de Isaac (1596), São João Batista (1597-8) ou A flagelação de Cristo (1607), por exemplo, o olhar das personagens, os corpos desnudos e o modo pelo qual estão dispostos, se entrelaçam ou foram iluminados deixam ver uma forte dimensão homoerótica ${ }^{3}$.

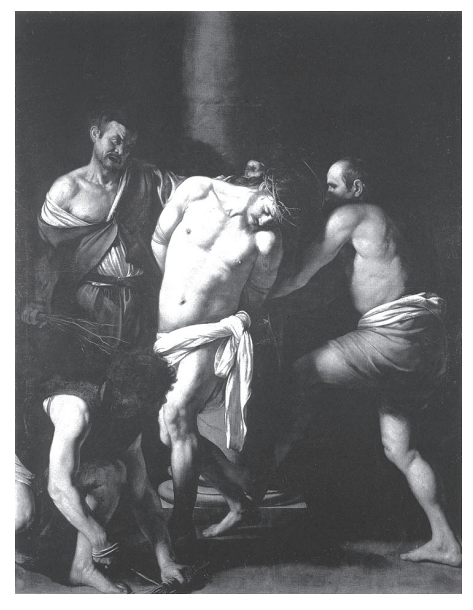
No quadro A flagelação de Cristo (imagem ao lado) o corpo iluminado ocupa o centro da imagem. O jogo dramático de luz e sombra entre o fundo e o primeiro plano da imagem valoriza a representação corporal. A continuidade entre os tecidos brancos amarra pela cintura o corpo de Cristo e do flagelador à direita. Uma linha imaginária perpendicular tem início no ombro desnudo do homem à esquerda e termina no pé descalço do homem à direita, acentuando os aspectos do torso e do abdômen do corpo central. A roupa escura do homem agachado à esquerda valoriza a perna que sustenta a inclinação do corpo de Cristo. A inclinação e a valorização dos membros aumentaram o vigor, a força e a beleza dos corpos e, por consequência, criaram condições à excitação dos sentidos eróticos das imagens.

A partir do final do século XIX, as imagens renascentistas de São Sebastião foram revisitadas e ele se tornou um ícone da homossexualidade masculina. $\mathrm{O}$ santo foi retratado com fortes características andróginas, como podemos ver na obra $O$ martírio de São Sebastião (1536-8), do artista português Gregório Lopes.

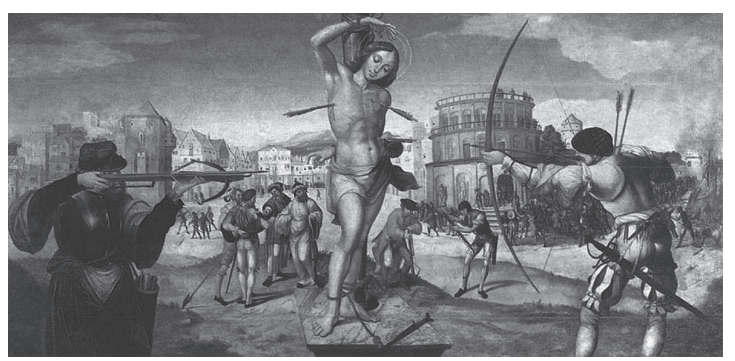

$\mathrm{Na}$ imagem, Sebastião, mesmo tendo o corpo atravessado por flechas, mantinha-se ereto, belo e com um discreto sorriso. As posições dos pés, da perna e da mão sobre a cabeça conferiram uma sensualidade feminina ao corpo do santo. A leveza e a transparência 
do tecido que cobre a pélvis acentuam o erotismo da imagem. A identificação dos homossexuais com o santo estava na metáfora daquele que, mesmo no momento máximo de sua perseguição e agonia, se mantém belo. Oscar Wilde, após sua condenação a prisão por crimes contra a natureza, em 1895, passou a usar o pseudônimo Sebastian.

As imagens, nos casos descritos acima, possuem uma função de mediação entre os sujeitos e o mundo. Para além de símbolos sagrados, elas têm a função de duplo, de produzir uma sensação específica a partir do uso dos gestos dos corpos nos quadros. São as experiências estéticas anteriores do leitor que oferecem condições para a interpretação das imagens. Todos os materiais expressivos elencados na composição da imagem dependerão das experiências visuais do observador para produzirem sentido. $\mathrm{Na}$ busca pelas sensações específicas, as imagens necessitam combinar sua função de conhecimento à função estética. "[...] os instrumentos plásticos de qualquer imagem tornam-na um meio de comunicação que solicita o prazer estético e o tipo de recepção a ele vinculado" (Joly, 1996, p. 60).

\section{O corpo resiste com delicadeza}

Quando em 1870, o psiquiatra alemão Carl Westphal, no artigo "As sensações sexuais contrárias", definiu o homossexual como portador de uma identidade sexual doentia, foi trazido à cena cultural um sujeito com características próprias. Se até então a busca pelo prazer em um corpo do mesmo gênero era uma ação pecaminosa, resultado das tentações demoníacas, a caracterização como enfermidade conferiu limites identitários ao homossexual. À época, essa forma de desejo definiu um grupo específico de pessoas. Rapidamente, um conjunto de símbolos foi gerado com o objetivo de identificar o corpo do invertido. Seguidores dos preceitos de Cesare Lombroso se adiantaram em buscar nos corpos dos homossexuais uma compleição física tipificadora: ombros frágeis, alterações da glândula mamária, traços delicados da face. No corpo, médicos e psiquiatras investigavam quais sintomas e funcionamentos bioquímicos eram capazes de homogeneizar o homossexual. A patologização das práticas sexuais entre gêneros iguais colocou em evidência a personagem homossexual e seu corpo, os transformado em objeto de investigação e vigilância, visando sempre deter o controle sobre sua representação.

No terreno das imagens, a moda e os modos masculinos trataram de inscrever claramente o que seria e como se vestia um corpo heterossexual: as roupas dos homens ganharam desenhos que valorizavam o masculino e afastavam qualquer aspecto feminino das vestimentas. Todavia, um grupo reagia aos padrões estéticos e ao comportamento heterossexual dominante: os dândis. Esse movimento contracultural reunia intelectuais e artistas que produziam sua linguagem através da vestimenta e dos gestos. Em sua ética, os dândis se portavam como seres criadores de beleza. Eles usavam a imagem para marcar sua diferença, trajavam peças extravagantes, não se preocupavam em carregar em suas roupas aspectos femininos e estavam interessados em romper com as características uniformizantes da sociedade industrial. Os dândis eram homens extremamente preocupados com a elegância e a beleza. Para eles a imagem física, a apresentação pessoal era o que mais importava. $\mathrm{O}$ dandismo inaugurou um novo erotismo masculino, embalado em calças justas, camisas de ceda e casacos modelados ao corpo. Ao final do século XIX, a imagem dos dândis foi associada ao estilo do homossexual urbano.

Mike Featherstone (1995) considera que o dandismo entendeu a estetização da vida cotidiana como uma oportunidade para transformar a vida em obra de arte. Sustentada na aparência, a vida dos seguidores do movimento estava pautada pelo gosto estético. Para Featherstone, a radicalização na busca pela originalidade e a superioridade dada no vestir e na relação com os objetos pessoais, o desprezo ao massificado associado a uma "aristocracia de espírito", fez do dandismo a base para aquilo que hoje nominamos estilo de vida.

\section{O retrato do afeto entre corpos masculinos como alimento à experiência visual}

No ano de 2001, a exposição Dear Friends American Photographs Of Men Together 1840 - 1898, no International Center of Photography de Nova York, revelou para os seus visitantes instantes homoafetivos entre homens anônimos registrados no início da fotografia nos Estados Unidos da América. Nos diversos formatos das imagens fotográficas da exposição, o espectador podia ver essa manifestação afetiva nos gesto dos fotografados: braços que se cruzavam, corpos que se tocavam e olhares lânguidos que inspiravam sentimentos profundos. Todavia, os queridos amigos que habitavam aquelas imagens não eram necessariamente homossexuais. 
Apesar de sua forte carga homoerótica, uma das possibilidades de aceitação daquelas imagens à época foi atribuída à extrema valorização da amizade entre homens naquele país. No século XIX, a classe média americana mantinha uma clara distância entre o universo feminino e o masculino. Dentro das fronteiras de gênero ocorreram muitas maneiras de relações afetivas entre pessoas do mesmo sexo.

De acordo com o catálogo da exposição, estimulados pelas considerações do jornalista Horace Greeley, que em 1853 publicou um artigo sobre a capacidade única dos retratos em registrar as emoções das pessoas, muitos homens resolveram documentar o clima de amizade e camaradagem presente nas relações com seus melhores amigos. A curadoria do evento relembrou que a cultura neoclássica existente nos EUA, entre os anos de 1830 e 1840, estimulou o aparecimento de três modelos de relação afetiva entre homens: o primeiro modelo foi o do gentleman, homens de modos europeu que valorizavam uma amizade de princípios românticos, com referências a relações clássicas como as de Platão e Aristóteles ou Aquiles e Pátroclo; o segundo modelo foi o amor fraternal, decorrente da troca de informações entre norte-americanos e britânicos que cultivavam os princípios abolicionistas, modelo que aproximou os homens pela ideologia política e pela inspiração naquilo que acreditavam ser a forma de amor ideal, o amor cristão que pregava a igualdade entre os homens, amavam-se como Cristo amou seus apóstolos; o terceiro modelo caracterizada pelo conceito do poeta Walt Whitman de comradely love, o amor existente entre os soldados, os heróis de guerra, entre aqueles que construíram ombro a ombro a nação norte-america. A possível combinação desses tipos de amizade produziu uma tolerância à manifestação física de afeto entre homens.

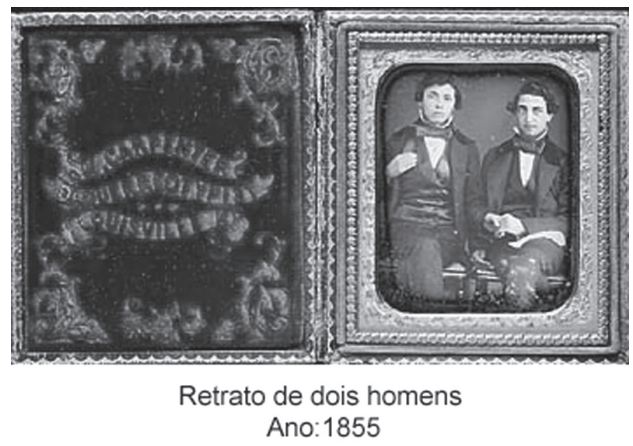

Sob esta guarda de tolerância, vários homossexuais aproveitaram a oportunidade para eternizar nas imagens fotográficas um momento com seu par. Algumas imagens reproduziam o padrão aplicado em fotos de casal heterossexual, marido à direita e esposa à esquerda dando a mão ao marido. Ao lado do gestual e da posição dos corpos, a escolha das roupas pelas personagens das imagens deixava ver nas fotos os elementos de uma estética homossexual.

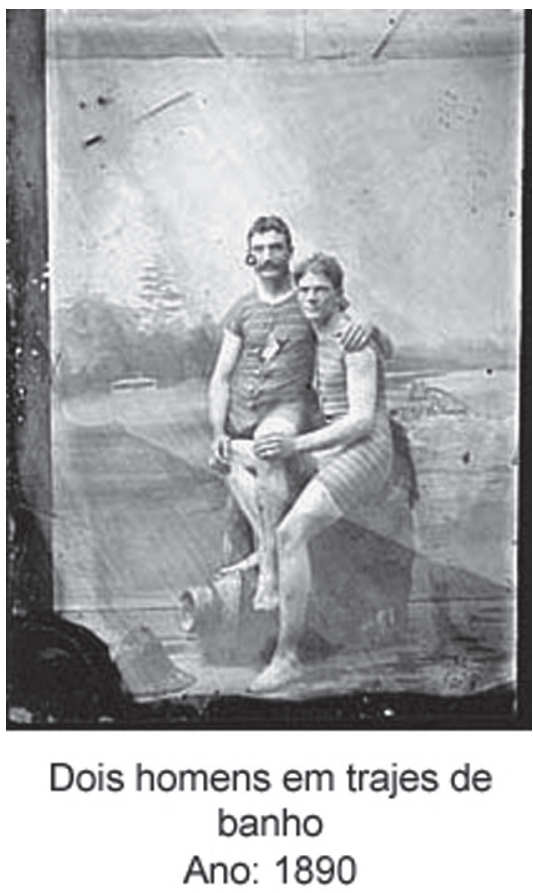

Mesmo não sendo necessariamente homossexuais, a escolha feita por um objeto estético para registrarem suas relações de afetos fez daqueles homens comuns colaboradores da composição do repertório imagético da experiência visual homossexual. Os gestos, as roupas, as poses deram contornos a manifestação de um desejo de estar junto expresso por pessoas do mesmo gênero. Se, como afirmou Dewey, a experiência educa os sujeitos, a experiência visual com aquelas imagens pôde, em seu tempo, ajudar a modificar a impressão sobe o encontro entre corpos masculinos.

\section{O corpo do homem em revista}

No apagar das luzes do século XIX, dois alemães iniciaram o registro fotográfico de corpos masculinos com um acentuado apelo homoerótico: os primos Wilhelm von Gloeden e Guglielmo von Plüschow. Os dois se mudaram para a Itália e ali investiram na fotografia. O Barão de von Gloeden, na pequena cidade de Taormina, na costa italiana, e Plûschow na cidade 
de Nápoles, produziram uma grande quantidade de imagens de nus masculinos. Utilizando como modelos os homens da população local, essas imagens configuramse como um expoente da arte homoerótica. Reproduzindo a ambiência da Grécia antiga no cenário urbano de Taormina, von Gloeden e Plüschow se transformaram em pioneiros da fotografia feita ao ar livre. $\mathrm{O}$ cuidado estético na produção das imagens rendeu várias premiações aos fotógrafos nos salões europeus e foram divulgadas em revistas dedicadas a fotos artísticas. O sucesso das imagens incentivou os fotógrafos a produziram catálogos com suas imagens que rapidamente chamaram a atenção do público homossexual. A circulação desse tipo de peça gráfica tornou-se um negócio lucrativo até o princípio da I Primeira Guerra Mundial, quando a igreja e os governos de vários países proibiram a veiculação do material.

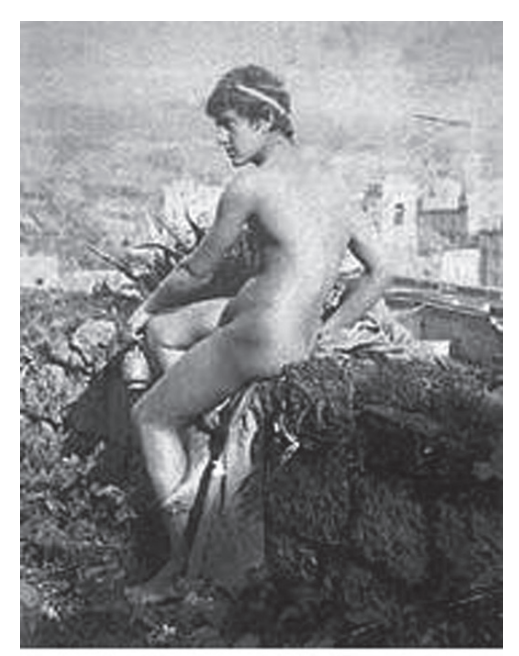

Foto: Wilhelm von Plüschow Modelo Vincenzo Galdi Nápoles, 1890
Entre os anos de 1930 e 1960, fotógrafos como o alemão Herbert List e os americanos George Platt Lyness e Bruce of Los Angeles produziram um número significativo de imagens de corpos masculinos com apelo homoerótico. Ao mesmo tempo em que produziam imagens artísticas, eles fotografaram para agências de imagens e revistas de moda: Herbert List trabalhou na agência Magnun e George Platt Lyness fotografou para a revista Vogue.

Entre a Primeira e a Segunda Guerra Mundial, o aumento na produção e na circulação de fotografias do corpo masculino deu início a uma transformação na imagem do corpo do homem. A prática do culto ao corpo masculino entrou em cena e junto com ela um grande número de revistas destinadas ao fisiculturismo. Entretanto, os consumidores dessas revistas nem sempre eram apenas gente interessada em esporte - mulheres e gays tornaram-se consumidores. Ao perceberem o comportamento do público, alguns produtores investiram na mudança da estética das imagens, que ficavam cada vez mais carregadas no erotismo.

Em 1951, Bob Mizer criou em Los Angeles, EUA, a Physique Pictorial (PP), revista do Atbletic Model Guide (AMG), estúdio de fotografias homoeróticas fundado por Mizer em 1945. A divulgação de conteúdo homoerótico era proibida por lei. Por isso, Mizer sofreu várias perseguições judiciais sob a acusação de promover a homossexualidade. Em 1968, a revista Grecian Guild
Pictorial venceu uma ação na Suprema Corte Americana com o argumento que suas fotografias de nus masculinos eram objetos artísticos. Estava inaugurada uma nova fase de crescimento para este tipo de publicação.

O corpo masculino representado na revista Physique Pictorial era sempre atlético e adornado com traços dos heróis. Os corpos estavam carregados das marcas do poder masculino. $\mathrm{O}$ trabalho de Bob Mizer possui um diálogo intenso com as imagens de Bruce of Los Angeles. Esta característica de representação do corpo chamou a atenção de um jovem ilustrador da Finlândia, Touko Laaksonen. As imagens que Touko criavam reproduziam os homens de sua infância no interior do país: lenhadores e trabalhadores do campo. Em 1939, Touko Laaksonen mudou-se para Helsink para estudar artes. Quando o exército alemão invadiu a Finlândia, os soldados tornaram-se objetos sexuais e de inspiração criativa para ele. Quando não havia sexo, Touko criava "desenhos sujos" para imaginar sua masturbação. Em 1956, sob o pseudônimo Tom, o ilustrador enviou uma série à Bob Mizer. Em 1957, as imagens de Tom foram capa da Physique Pictorial e adquiriram grande sucesso. Desde então, ele se transformou em Tom of Finland. A partir de seu trabalho houve uma inversão na representação do corpo do homem homossexual. Até então, os homossexuais eram vistos como frágeis réplicas do corpo feminino. Os "desenhos sujos" de Tom of Finland retratavam o encontro homoerótico de homens fortes e belos. Enquanto as fotografias dos homens americanos do século XIX mostraram que poderia haver menos aspereza no toque afetivo entre dois homens, as imagens produzidas por Tom comunicavam que homossexuais poderiam ser também fortes e viris.

A combinação efefuada
pelos homossexuais de
elementos das artes e dos
media plasmou, a partir do
século XX, uma forma distinta
pelos homossexuais de elementos das artes e dos século XX, uma forma distinta 


\section{daquelas que 0 discurso normativo dava a seus corpos. A provocação das imagens foi um gesto éfico e estéfico.}

Remontando novamente ao pensamento de Dewey, a inserção de novos padrões, sejam eles éticos ou estéticos, é fundamental no processo educacional da humanidade. É pelo acumulo das experiências anteriores que o sujeito obtém conhecimento e parâmetros para aferir novos valores e condições de se ariscar em novas vivências e experiências.

\section{O dandismo abaixo do Equador}

Mike Featherstone realça que entre as características do dandismo havia uma "preocupação heróica" com a originalidade no vestuário. Essa originalidade era uma atitude de superioridade frente ao que estava sendo massificado pelos novos meios de produção. A estetização dos dândis ultrapassava as roupas e chegava ao gestual do corpo. Como lembrou Featherstone, os dândis pretenderam transformar a vida em obra de arte. Sob o ângulo dessa pretensão abrigava-se um processo de consumo estético aliado a uma forma de vida que promovia o prazer estético. Essa angulação, nos termos de Featherstone, foi o ponto de partida para a procura de "novos gostos e sensações e à construção de estilos de vida distintivos, que se tornaram aspectos centrais da cultura de consumo.” (Featherstone, 1995, p. 100)

\section{Quase dois séculos depois do início do dandismo com Beau Brumel na Inglaterra, a estetização da vida cotidiana fornou-se uma fantasia do consumo de massa pós-moderno}

(Beck; Giddens; Lash, 1997; Featherstone, 1995). Nesta medida, o consumidor poderia olhar com uma disposição estética até os objetos mais banais da vida cotidiana - lembremos aqui o design dos objetos de cozinha, os detalhes internos dos carros, as embalagens de produtos para cuidados pessoais, por exemplo. $\mathrm{O}$ modo particular de vestir dos dândis preanunciou a inserção da estética nos territórios da moda. Território de transformação veloz, a moda contemporânea aponta para uma diversidade de estilos vida. Vestir ultrapassou a função de cobrir o corpo, é uma oportunidade para reinventar o corpo.

A estetização do corpo do homossexual masculino nos séculos XIX e XX funcionou como caminho para a autodeterminação ao mesmo tempo em que favoreceu o trânsito de novas maneiras de vinculação social do grupo. Nas imagens de divulgação da moda contemporânea, veiculadas nas revistas de comportamento e estilo segmentadas para o público homossexual, podemos perceber traços que revelam a influências das experiências visuais dos períodos anteriores. Compostas em momentos em que a manifestação do desejo pelo igual era feita de forma velada, aquelas imagens ensinaram aos homossexuais como representar seus corpos e seus desejos. O editorial "Muito além do jardim”, publicado em novembro de 2008, na edição de número 08 da revista brasileira Junior nos oferece uma boa oportunidade para observarmos como os elementos das imagens produzidas em tempos passados dialogam com a composição das imagens atuais.

Com foco nos temas de moda, comportamento e estilo, a revista Junior é segmentada para o público homossexual. Na seção portfólio dessa edição há uma homenagem ao fotografo Bob Mizer. Foram veiculadas
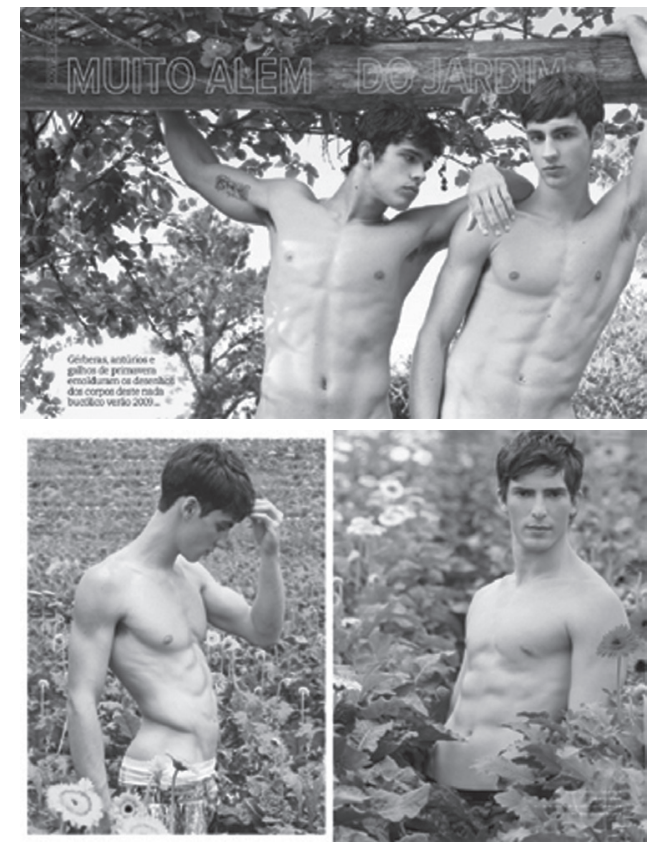
na Junior cinco imagens do acervo do fotógrafo americano. As imagens de Mizer têm corpos jovens, atléticos e fortes executando gestos que remontam a atividades lúdicas.

"Muito além do jardim" retrata dois homens jovens, ambos de uma beleza singela, em um ambiente edênico. Há nas fotos um clima brejeiro, tanto nos momentos em que os corpos foram registrados juntos, quanto nos que estão separados. Ao observamos a composição das imagens é possível reconhecer a ressonância do trabalho de von Gloeden e Plüschow e de Herbert List, em especial. Esta ressonância pertence ao horizonte de expectativa das imagens, tal como caracterizou esta noção Hans Robert Jauss. (Joly, 1996, p. 59-62) Proposta por Jauss para pensar a recepção das obras literárias, a noção serve bem aos estudos destas imagens. Ao interpretarmos o editorial de moda como texto verbo-visual, conferimos a ele o caráter de discurso estetizado que combina elementos dos gêneros jornalístico e publicitário. A recepção do editorial partirá de um contexto produzido pelas experiências visuais anteriores do leitor, ou seja, remontará aos instantes em que a percepção estética desse leitor se formou. Mesmo que não tenha sido exposto diretamente às imagens de List ou de von Gloeden e Plüschow, a maneira como estes artistas estetizaram o corpo pode ser vista em outros meios, fato que auxiliou na definição da percepção estética que o leitor da revista tem do corpo e da representação do homossexual masculino.

Um editorial que começa com corpos sem roupa apresenta a estilização corporal como moda, a forma corporal como modo de representação identitária. Se o conteúdo de uma imagem pode generalizar o grupo para o qual ela se dirige, o horizonte de expectativas pode particularizar sua recepção. Mesmo que a forma corporal desagrade visualmente, os gestos dos corpos podem inscrever, na composição das imagens, outro tipo de prazer estético. $\mathrm{Na}$ foto ao lado, o toque das mãos nas pernas tem o duplo sentido do gesto aprendido em brincadeiras entre meninos - sustentar o corpo do outro para saltar o muro alto ou alcançar um galho de árvore, por exemplo - ao mesmo tempo em que pode representar a intimidade do afago homoerótico. Como nas fotografias da exposição Dear Friends, a atribuição de valor ao gesto dependerá da experiência de quem o vê.

Ao se lançarem às experimentações estéticas estimuladas pelo dandismo ou pertencentes ao terreno das imagens - que serviam à comunicação quando a comunicação verbal foi silenciada, os homossexuais elevaram à máxima potência a capacidade de expressão de seus corpos. Há no corpo uma série de elementos ativos na construção da experiência e na recepção estética. Estes elementos ativos são produzidos e reunidos em espaços e tempos bem marcados. Cada momento vivido na experiência é um contributo para entendermos a totalidade desse exercício de estetização. Neste sentido, devemos nos ater à maneira como as escolhas estéticas responderam aos momentos socais aos quais estavam submetidas. As marcas estéticas de cada época não estão apenas nos objetos, elas se inscrevem também nos corpos, em suas formas e seus gestos. Se no século XIX o discurso médico e legal imprimia sobre o corpo homossexual o sentido de corpo invertido, criminoso e enfermo, restou aos homossexuais buscar a beleza e a perfeição para representar seus corpos. Próximos ao ideal clássico grego, a perfeição representava o corpo que carregava um valor moral positivo. A beleza dos corpos e das faces remonta dos modelos do editorial remonta a este ideal. Estes novos dândis têm a pele como o tecido de sua veste e a modelagem do corpo como o corte de sua roupa. Ao lado dos gestos o colorido tropical adorna o corpo. Os tons de verde das folhas sobrepostos pelo vermelho da inflorescência antúrios iluminam as espádices amarelas, conferindo as formas bastonadas um sentido erótico. Estas espádices metaforizam o falo que está oculto nas imagens. Em sua observação estética do editorial o leitor encontra outra forma de vestir o corpo

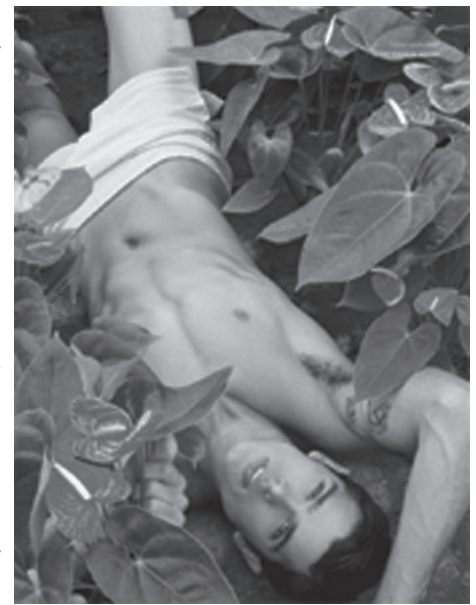




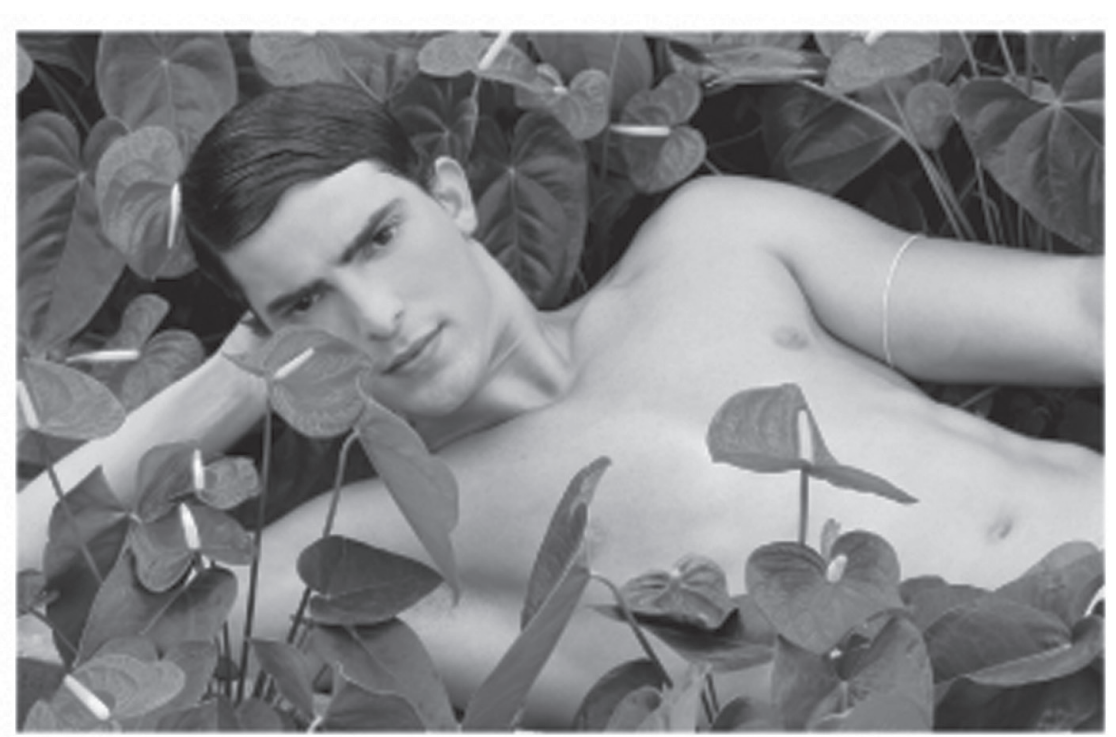

imagem agradável que singularizasse o grupo e funcionasse no sentido oposto à imagem produzida pelo discurso médico e jurídico de corpo invertido, sujeito patologizado e abjeto. Como estratégia de resistência a estes discursos estigmatizadores, restou aos homossexuais investir na criação de um mundo que se justificasse por sua qualidade estética.

A experiência estética entre o leitor e os objetos artísticos, literários ou midiáticos, carregados de materiais expressivos do mundo homossexual, permitiu e ainda permiti aos sujeitos descobrir condições de emancipação,

e usar seus gestos para expressar sua moda.

A moda de massa no século XX figurou uma estética popular. Essa estética auxiliou muitos indivíduos a se particularizarem na multidão ou se misturarem a ela. Se no renascimento foram as artes plásticas que serviram à comunicação silenciosa dos homossexuais, a partir do final da modernidade a moda também passou a comunicar por imagens, porém de uma maneira nada silenciosa. Para afirmar o presente a moda volta ao passado. Nesse deslocamento, iconografias passadas são revisitadas e em alguns momentos apenas alguns traços são capazes de expressarem a totalidade de seu conteúdo. A postura corporal dos modelos nas imagens ao lado reconstrói a imagem do corpo de São Sebastião. A posição dos braços remete à valorização do torso e do abdômen tal como nas imagens renascentistas do santo. O que há entre os corpos dos modelos e as imagens de São Sebastião é a passagem de uma ordenação simbólica que não cessará no leitor (Sant'Anna, 2001; Saltzman, 2007).

Seja no visual dos dândis europeus, nas imagens dos homens anônimos da exposição norte-americana Dear Friends, nas fotografias de nus masculino feitas pelos fotógrafos do século XX ou no editorial de moda da revista Junior, o que podemos perceber é que a sobrevivência dos homossexuais esteve absolutamente relacionada às suas escolhas estéticas. Mais que respeitar uma racionalidade, houve na eleição dos modos, roupas e objetos que cercavam os homossexuais uma opção por um estilo estético. Tal estilo organizou o mundo destes sujeitos a partir de gostos estéticos semelhantes e não apenas a partir de práticas sexuais semelhantes. As escolhas estéticas pretenderam a produção de uma oportunidade de enxergar uma nova realidade a partir do reconhecimento da existência de seus iguais. Em síntese, estes leitores encontram nos discursos, que tratam de mundos semelhantes ao seu, modelos de ação que podem ser tomados como instrumentos de resistência aos discursos dominantes, como possibilidades de interação distintas às vividas, abrindo uma janela para o que poderia e pode vir a ser.

\section{REFERÊNCIAS}

BECK, Ulrich; GIDDENS, Anthony; LASH, Scott. Modernização reflexiva: política, tradição e estética na ordem social moderna. São Paulo: UNESP, 1997.

BETH, Hanno; PROSS, Harry. Introducción a la ciencia de la comunicación. Barcelona: Anthropos, 1990.

DEWEY, Jhon. Experiência e natureza; Lógica: a teoria da investigação. In: DEWEY, Jhon. $A$ arte como experiência; Vida e educação; Teoria da moral. São Paulo: Abril Cultural, 1980.

FEATHERSTONE, Mike. Cultura de consumo e pósmodernismo. São Paulo: Studio Nobel, 1995.

SALTZMAN, Andréa. El cuerpo diseñado. Sobre la forma en el proyecto de la vestimenta. Buenos Aires: Páidos, 2007.

SANT'ANNA, Denise B. Corpos de passagem: ensaios sobre a subjetividade contemporânea. São Paulo: Estação Liberdade, 2001. 


\section{NOTAS}

* Trabalho apresentado ao Grupo de Trabalho "Estéticas da Comunicação”, do XVIII Encontro da Compós, na PUC-MG, Belo Horizonte, MG, em junho de 2009.

${ }^{2}$ Dewey incorporou fortemente os princípios das teorias evolucionistas em seus trabalhos. Por isto, em sua obra aparece a descrição das habilidades humanas em continuidade a história natural das espécies.

${ }^{3}$ Diferentemente de outros artistas de seu tempo, Caravaggio investiu na explicitação dos aspectos eróticos em seus quadros. À época, alguns críticos chegaram a classificar sua pintura como escandalosa. 